\title{
Association of number of siblings, birth order, and thinness in 3- to 12-year-old children: a population-based cross-sectional study in Shanghai, China
}

Tingting Yu ${ }^{1,2 \dagger}$, Chang Chen ${ }^{1,2,3 \dagger}$, Zhijuan Jin ${ }^{4}$, You Yang ${ }^{4}$, Yanrui Jiang ${ }^{4}$, Li Hong ${ }^{5}$, Xiaodan Yu²,3,4 Hao Mei ${ }^{2,6}$, Fan Jiang ${ }^{2,3,4}$, Hong Huang ${ }^{1,3^{*}}$, Shijian Liu ${ }^{1,2,3^{*}}$ (i) and Xingming Jin $^{3,4,7}$

\begin{abstract}
Background: Sibship size and structure have a significant association with overweight and obesity in children, but the relationship with thinness has not been fully studied and understood, especially in Asia. This study evaluated the associations among number of siblings, birth order, and childhood thinness and investigated the association of number of younger or older siblings with childhood thinness.

Methods: In this study, we performed a population-based cross-sectional study among 84,075 3- to 12-year-old children in Shanghai using multistage stratified cluster random sampling. We defined grades 1, 2, and 3 thinness according to the body mass index cutoff points set by the International Obesity Task Force and used multinomial logistic regression models to estimate the odds ratio (OR) and 95\% confidence interval (95\% Cl).

Results: Compared with only children, for boys, children with two or more siblings were more likely to suffer from grade $2(\mathrm{OR}=1.29,95 \% \mathrm{Cl} 1.02,1.64)$ and grade 3 thinness $(\mathrm{OR}=1.60,95 \% \mathrm{Cl} 1.07,2.40)$; and the youngest child faced a higher risk of grade $2(\mathrm{OR}=1.44,95 \% \mathrm{Cl} 1.09,1.90)$ and grade 3 thinness $(\mathrm{OR}=1.53,95 \% \mathrm{Cl} 1.01,2.33)$. For girls, children with one sibling were more likely to suffer from grade 1 thinness $(\mathrm{OR}=1.22,95 \% \mathrm{Cl} 1.05,1.42)$; the oldest child, middle child, and youngest child faced a higher risk of grade $1(\mathrm{OR}=1.42,95 \% \mathrm{Cl} 1.09,1.84)$, grade 2 $(\mathrm{OR}=1.26,95 \% \mathrm{Cl} 1.03,1.54)$, and grade 1 thinness $(\mathrm{OR}=1.87,95 \% \mathrm{Cl} 1.21,2.88)$ respectively. There was no statistically significant relationship, however, between a larger number of younger or older siblings and childhood thinness.

Conclusions: Regardless of sex, having either siblings or a higher birth order was positively associated with childhood thinness. The present study has suggested that future interventions to prevent childhood thinness should consider family background as an important factor, especially in multi-child-families.
\end{abstract}

Keywords: Number of siblings, Birth order, Thinness, Children

\footnotetext{
*Correspondence: huanghong@smhb.gov.cn; liushijian@scmc.com.cn

${ }^{\dagger}$ Tingting Yu and Chang Chen contributed equally to this work.

'School of Public Health, Shanghai Jiao Tong University School of Medicine, Shanghai, China

Full list of author information is available at the end of the article
}

C C The Author(s). 2020 Open Access This article is licensed under a Creative Commons Attribution 4.0 International License, which permits use, sharing, adaptation, distribution and reproduction in any medium or format, as long as you give appropriate credit to the original author(s) and the source, provide a link to the Creative Commons licence, and indicate if changes were made. The images or other third party material in this article are included in the article's Creative Commons licence, unless indicated otherwise in a credit line to the material. If material is not included in the article's Creative Commons licence and your intended use is not permitted by statutory regulation or exceeds the permitted use, you will need to obtain permission directly from the copyright holder. To view a copy of this licence, visit http://creativecommons.org/licenses/by/4.0/. The Creative Commons Public Domain Dedication waiver (http://creativecommons.org/publicdomain/zero/1.0/) applies to the data made available in this article, unless otherwise stated in a credit line to the data. 


\section{Background}

Preschool- and school-age years are critical periods for a child's growth and development. During these stages, children experience rapid but incomplete physical and psychological development, causing them to be the most vulnerable group in the population. Thus, children require more attention and support from family and society $[1,2]$. With the rapid development of the economy and the advancement of urbanization, the double burden of obesity and thinness has become increasingly prominent in many developing countries [3-5]. Although the prevalence of overweight and obesity has received considerable attention in China, many researchers have shown that childhood thinness is also an important public health problem that cannot be ignored. In 2010, China had a thinness rate of $9.0 \%$ among children ages 6 to 17 years old, including $10.4 \%$ for boys and $7.3 \%$ for girls [6]. In Shanghai, the prevalence of thinness was $13.92 \%$ for boys and $18.45 \%$ for girls ages 3 to 12 years old [7].

Thinness is an indicator of recent undernutrition and eating disorders and often is associated with physical, mental, and intellectual development problems, as well as a higher risk of metabolic disease in adulthood [8-10]. Families play a vital role in the intervention of children with undernutrition, and studies have reported that family structure affects childhood physical development [11-13]. In one-child families, parents and grandparents pay all their attention to their single child or grandchild. Excessive doting by family members has resulted in childhood overweight and obesity [14]. In multi-child-families, however, with an increase in the number of siblings, parents' time, energy, and financial resources are diluted among their children [15]. Studies have found that sibship composition is significantly associated with childhood obesity or undernutrition (thinness, stunting, or underweight) [13, 16-22]. Most studies have supported the finding that children who have siblings and older children have a lower risk of being overweight or obese [13, 16-19]. Results illustrating the associations of the number of siblings and birth order with undernutrition were inconsistent, however. Some studies found that a child's risk of undernutrition was higher as the birth order or number of siblings increased [20-22]. A previous study reported that a larger number of siblings increased the odds ratio for thinness for girls but not for boys [23]. By contrast, one study showed no relationship between the number of siblings or birth order and thinness [24].

To change the demographic structure, China has introduced several family-planning policies, including the one-child policy, which was introduced nationwide in 1980 (except for ethnic minorities and rural families where the first child was a girl) but that was influenced by region, parental educational level, family economic level, and other factors during its implementation period; and the two-child policy, which was adopted for families with one parent as the only child in 2013 and then implemented nationwide in 2016 [25]. China became the country with the largest population of only children in the world (about 100 million) as a result of this one-child policy [26]. However, with the implementation of China's two-child policy, family structure and personal relationships, especially sibling structure and relationships, became increasingly complicated and have had an unpredictable effect on childhood health. Therefore, after excluding the influence of early life nutrition, childhood living habits, and family economic level, which all were related to sibship composition and childhood thinness, this study evaluated the influence of sibship size and structure on childhood thinness and discerned whether sex interaction existed between them.

\section{Methods}

\section{Study design and participants}

This investigation was based on a large school-based crosssectional study that was part of a population survey of autism spectrum disorders led by the government. Relevant sampling methods have been described in a previous study [7] and are briefly stated as follows. This study was conducted using multistage, stratified cluster random sampling among children ages 3 to 12 years old in Shanghai, China, in June 2014. We randomly selected three urban districts and four suburban districts from a total of 17 districts across Shanghai. In total, 134 of 949 (14.12\%) kindergarten schools, as well as 70 of $436(16.06 \%)$ primary schools, were randomly sampled from a set of schools located in the selected districts (Fig. 1). In total, 84,075 of 576,621 (14.58\%) children were recruited from these selected schools according to the proportion of students in each district to all of the sampled districts.

The child's family, social environment, and growth questionnaires were administered to teachers, who accepted uniform training on completing, distributing, and collecting the questionnaires. Teachers informed their students to take the questionnaire home, and then the students' parents were asked to complete the questionnaire to collect multilevel information on the child's characteristics (e.g., age, sex, weight, height, number of siblings, birth order, birthweight, feeding pattern, parental ages at childbirth, workday TV time, Internet use time, and snacking frequency) and family structure (e.g., parental weight status, parental education level, family income and residential site). Then, the teachers collected the completed questionnaires and returned them to the investigators. Questionnaires with key information missing, including height, weight, number of siblings, or birth order, were excluded in the final analysis.

\section{Measurement}

Body mass index $\left(\mathrm{BMI}, \mathrm{kg} / \mathrm{m}^{2}\right)$ was calculated as weight $(\mathrm{kg})$ divided by height $(\mathrm{m})$ squared. Thinness, overweight, and 


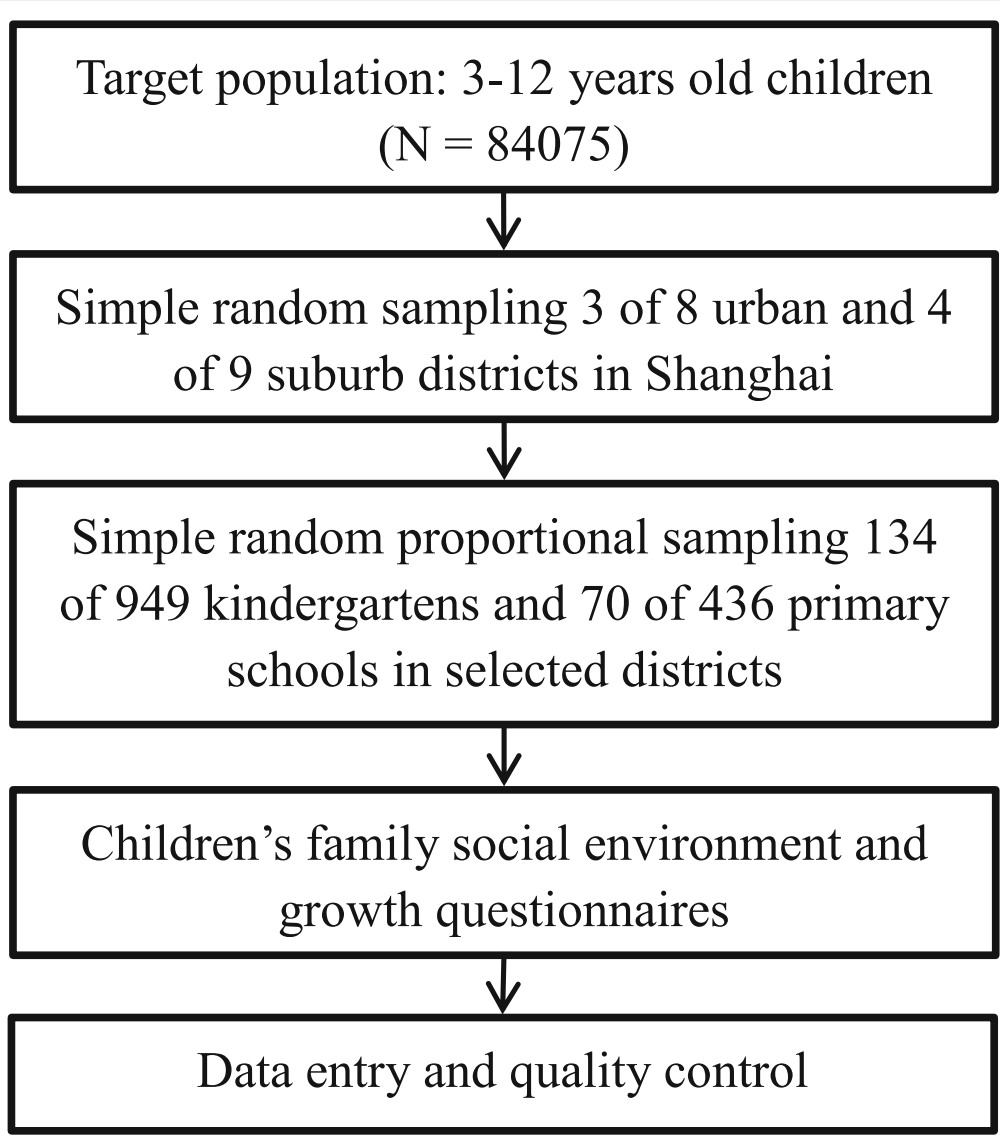

Fig. 1 Study flowchart using multistage and stratified cluster random sampling

obesity were defined according to the International Obesity Task Force-recommended age- and sex-specific cutoff points for children ages 2 to 18 years old. The BMI cutoffs for grades 1,2 , and 3 were $<18.5,<17.0$, and $<16.0 \mathrm{~kg} / \mathrm{m}^{2}$, respectively, and the cutoff for overweight was $\geq 25.0 \mathrm{~kg} / \mathrm{m}^{2}$. The cutoff for obesity was $\geq 30.0 \mathrm{~kg} / \mathrm{m}^{2}$, and the cutoff for severe obesity was $\geq 35.0 \mathrm{~kg} / \mathrm{m}^{2}[27,28]$. For adults, the weight status was categorized by BMI into underweight $\left(<18.5 \mathrm{~kg} / \mathrm{m}^{2}\right)$, normal weight $\left(18.5-25.0 \mathrm{~kg} / \mathrm{m}^{2}\right)$, and overweight $\left(\geq 25.0 \mathrm{~kg} / \mathrm{m}^{2}\right)$ classes, which included obesity and severe obesity as defined based on the World Health Organization cutoffs.

According to a previous study [17], we divided the number of siblings into three groups as follows: none (only child), one, and two or more siblings. We categorized birth order into four groups as follows: only child, oldest child, youngest child, and middle child. We included the number of younger or older siblings in three groups: none (only child), one, and two or more siblings. For birth order, the middle child represented children who had younger sibling(s) and older sibling(s). For the number of younger siblings, the one-sibling group or the two-or-more-siblings group represented the children who were the oldest child and who had either one or two or more younger siblings. For the number of older siblings, one or two or more siblings represented children who were the youngest child and who had either one or two or more older siblings.

Childhood characteristics included age (in years), sex (boy, girl), birthweight (<2500, 2500-4000, or $\geq 4000 \mathrm{~g})$, feeding pattern (breast-feeding, formulary-feeding, mixedfeeding), parental ages at childbirth $(<25,25-34$, or $\geq 35$ years old), workday TV time $(<1,1-3$, or $>3 \mathrm{~h}$ /day), Internet use time $(<2,2-4$, or $>4 \mathrm{~h} /$ day $)$, and snacking frequency $(0,1-3$, or $>3$ times/day) were considered as potential prenatal confounding factors [22, 24, 29]. Family characteristics included parental education level, which was divided into low (illiterate, primary school, or junior high school), middle (senior high school, technical school, or college), and high (undergraduate or above). Family income was categorized into three groups as follows: low $(<10,000,10,000-30,000$, or 30,000-50,000 Chinese yuan), middle (50,000-100, 000, 100,000-150,000, or 150,000-200,000 Chinese yuan), and high (200,000-300,000, 300,000-1,000,000, and $>1,000,000$ Chinese yuan), according to a social science definition [30]. Residential site was defined as urban or suburban residents according to the participants' living district. 


\section{Statistical analysis}

We used EpiData 3.1 (EpiData Association, Odense, Denmark) for data entry and applied a logic error check. To ensure the reliability, consistency, and correctness of inputted data, we randomly sampled $15 \%$ of questionnaires for repeat data entry. We obtained verbal consent from all participants and their parents before investigation. This study was approved by the Institutional Review Boards of the Shanghai Municipal Commission of Health and Family Planning.

All statistical analyses were conducted using the software package IBM SPSS Statistics (version 24.0). We computed sampling weights using inverse probability weighting, which represented the inverse of the combined selection probability in each sampling stage. Sample weight (Wt_Sample) was the product of the sampling weights and the nonresponse weight, which was calculated by the following equation:

$$
\begin{aligned}
W t_{-} \text {Sample }= & \text { Wt_Strat } 1 \times W t_{-} \text {Strat } 2 \\
& \times W t \_N R,
\end{aligned}
$$

where Wt_Strat1 is the inverse probability of an "urban district" or "suburban district" being selected in the central urban or suburban districts stratum in Shanghai, Wt_Strat2 represents the inverse probability of a "kindergarten" or "primary school" being selected in the kindergarten or primary school stratum in each selected district, and Wt_NR is the inverse probability of the nonresponse rate for questionnaires in each of the selected districts.

We used the Chi-square tests to compare the distribution of childhood and family characteristics, as well as prevalence of thinness among the groups for different numbers of siblings, birth order, number of younger siblings, and number of older siblings. Combing with LOGISTIC module in complex sampling, which considered sample weight and sampling method, we used multinomial logistic regression models to calculate the OR and $95 \% \mathrm{CI}$ of the number of siblings, birth order, number of younger siblings, and number of older siblings for grades 1,2 , and 3 thinness among boys and girls. We made additional adjustments for the multinomial regression models, including model I: adjusted for age, which was related to the BMI category; model II: adjusted for age and childhood characteristics, including birthweight, feeding pattern, parental age at childbirth, workday TV time, Internet use time, and snacking frequency, which were reported to be associated with sibship composition and BMI category; and model III: adjusted for age, childhood characteristics, and family characteristics, including parental weight status, parental education level, family income, and residential site, which could reflect the family resources for children to some degree. The statistical significance was defined as a $P$-value $<0.05$ by a twotailed test.

\section{Results}

A total of 84,075 questionnaires were distributed to participants ages 3 to 12 years old, and 81,384 completed questionnaires were collected with a response rate of $96.80 \%$. In total, 13,810 children $(16.97 \%)$ were excluded, among which 8949 (11.00\%) had incomplete height or weight data, and 4861 (5.97\%) had no data on number of siblings and birth order. We included 67,574 children in our final analysis, including 35,835 boys (53.03\%) and 31,739 girls (46.97\%).

Table 1 shows the characteristics of study participants arranged by the number of siblings. Overall, the number of children with no siblings (only child), one sibling, and two or more siblings were 49,097 (72.66\%), 6852 (10.14\%), and 11,625 (17.20\%), respectively. The average age (mean $\pm \mathrm{SD}$, standard deviations) of only children, those with one sibling, and those with two or more siblings was $7.03 \pm 2.30,6.99 \pm 2.25$, and $7.41 \pm 2.19$ years, respectively (not shown in the table). The proportion of boys in each number of sibling groups was higher than that of girls, especially in the one-child category $(p<$ $0.001)$. Low birthweight $(p=0.029)$ and breast-feeding $(p<0.001)$ and mothers $(p<0.001)$ or fathers $(p<0.001)$ aged at childbirth younger than 25 years old were more common in the two-or-more-siblings group. Workday TV time $(p<0.001)$, Internet use time $(p<0.001)$, and snacking frequency $(p<0.001)$ were statistically different in the groups with different numbers of siblings.

Family characteristics according to the number of siblings are shown in Table 2. In the only-child group, more children had fathers $(p<0.001)$ and mothers $(p<$ $0.001)$ who were underweight and more children were from urban residential families $(p<0.001)$. Most of the only children had a highly educated father $(p<0.001)$ or mother $(p<0.001)$ and had higher family income $(p<$ 0.001 ) than that of the children with siblings.

We calculated the prevalence of thinness in relation to the number of siblings, birth order, and number of younger or older siblings (the distribution is shown in Table 3). In general, the prevalence of thinness of only children (14.96\%) was lower than that of children with siblings (one sibling: 18.18\%; two or more siblings: $17.45 \%)$. In the only-, oldest-, middle-, and youngestchild groups, the prevalence of thinness increased as birth order increased (14.96, 17.73, 17.11, and 19.51\%, respectively). In the groups with different numbers of younger or older siblings, thinness was more common in the oldest child with two or more younger siblings $(18.31 \%)$ or in the youngest child with one older sibling (17.53\%). 
Table 1 Characteristics of study participants by the number of siblings

\begin{tabular}{|c|c|c|c|c|c|c|c|c|c|c|}
\hline \multirow[t]{2}{*}{ Variables } & \multicolumn{2}{|c|}{ None (only child) } & \multicolumn{2}{|l|}{ One } & \multicolumn{2}{|c|}{ Two or more } & \multicolumn{2}{|l|}{ Total } & \multirow[t]{2}{*}{$x^{2}$} & \multirow{2}{*}{$\begin{array}{l}P \\
\text { value }^{a}\end{array}$} \\
\hline & $\mathrm{N}$ & $\%$ & $\mathrm{~N}$ & $\%$ & $\mathrm{~N}$ & $\%$ & $\mathrm{~N}$ & $\%$ & & \\
\hline Sex & & & & & & & & & 32.94 & $<0.001$ \\
\hline Boy & 26,351 & 53.67 & 3457 & 50.45 & 6027 & 51.85 & 35,835 & 53.03 & & \\
\hline Girl & 22,746 & 46.33 & 3395 & 49.55 & 5598 & 48.15 & 31,739 & 46.97 & & \\
\hline Total & 49,097 & 100.00 & 6852 & 100.00 & 11,625 & 100.00 & 67,574 & 100.00 & & \\
\hline Birth weight (g) & & & & & & & & & 4.77 & 0.029 \\
\hline$<2500$ & 1631 & 3.32 & 417 & 6.09 & 939 & 8.08 & 2987 & 4.42 & & \\
\hline 2500-4000 & 41,584 & 84.70 & 5532 & 80.74 & 8712 & 74.94 & 55,828 & 82.62 & & \\
\hline$\geq 4000$ & 4883 & 9.95 & 722 & 10.54 & 1393 & 11.98 & 6998 & 10.36 & & \\
\hline Missing & 999 & 2.03 & 181 & 2.64 & 581 & 5.00 & 1761 & 2.61 & & \\
\hline Total & 49,097 & 100.00 & 6852 & 100.00 & 11,625 & 100.00 & 67,574 & 100.00 & & \\
\hline Feeding patterns & & & & & & & & & 8475.14 & $<0.001$ \\
\hline Breast Feeding & 21,893 & 44.59 & 3546 & 51.75 & 7411 & 63.75 & 32,850 & 48.61 & & \\
\hline Formulary Feeding & 7957 & 16.21 & 1054 & 15.38 & 1674 & 14.40 & 10,685 & 15.81 & & \\
\hline Mixed Feeding & 18,965 & 38.63 & 2194 & 32.02 & 2391 & 20.57 & 23,550 & 34.85 & & \\
\hline Missing & 282 & 0.57 & 58 & 0.85 & 149 & 1.28 & 489 & 0.72 & & \\
\hline Total & 49,097 & 100.00 & 6852 & 100.00 & 11,625 & 100.00 & 67,574 & 100.00 & & \\
\hline Workday TV time (hour/day) & & & & & & & & & $41,614.76$ & $<0.001$ \\
\hline$<1$ & 29,037 & 59.14 & 3762 & 54.90 & 5484 & 47.17 & 38,283 & 56.65 & & \\
\hline $1-3$ & 18,353 & 37.38 & 2843 & 41.49 & 5534 & 47.60 & 26,730 & 39.56 & & \\
\hline$>3$ & 990 & 2.02 & 135 & 1.97 & 303 & 2.61 & 1428 & 2.11 & & \\
\hline Missing & 717 & 1.46 & 112 & 1.63 & 304 & 2.62 & 1133 & 1.68 & & \\
\hline Total & 49,097 & 100.00 & 6852 & 100.00 & 11,625 & 100.00 & 67,574 & 100.00 & & \\
\hline Internet use time (hour/week) & & & & & & & & & $33,821.76$ & $<0.001$ \\
\hline$<2$ & 30,086 & 61.28 & 4518 & 65.94 & 7930 & 68.22 & 42,534 & 62.94 & & \\
\hline $2-4$ & 11,235 & 22.88 & 1346 & 19.64 & 1742 & 14.98 & 14,323 & 21.20 & & \\
\hline$\geq 4$ & 6301 & 12.83 & 717 & 10.46 & 769 & 6.62 & 7787 & 11.52 & & \\
\hline Missing & 1475 & 3.00 & 271 & 3.96 & 1184 & 10.18 & 2930 & 4.34 & & \\
\hline Total & 49,097 & 100.00 & 6852 & 100.00 & 11,625 & 100.00 & 67,574 & 100.00 & & \\
\hline Snack frequency (times/day) & & & & & & & & & $37,680.69$ & $<0.001$ \\
\hline 0 & 14,854 & 30.25 & 1951 & 28.47 & 2716 & 23.36 & 19,521 & 28.89 & & \\
\hline $1-3$ & 30,643 & 62.41 & 4355 & 63.56 & 7724 & 66.44 & 42,722 & 63.22 & & \\
\hline$>3$ & 2994 & 6.10 & 458 & 6.68 & 846 & 7.28 & 4298 & 6.36 & & \\
\hline Missing & 606 & 1.23 & 88 & 1.28 & 339 & 2.92 & 1033 & 1.53 & & \\
\hline Total & 49,097 & 100.00 & 6852 & 100.00 & 11,625 & 100.00 & 67,574 & 100.00 & & \\
\hline Father's age at child birth (years) & & & & & & & & & 976.81 & $<0.001$ \\
\hline$<25$ & 7217 & 14.70 & 1119 & 16.33 & 2263 & 19.47 & 10,599 & 15.69 & & \\
\hline $25-34$ & 33,800 & 68.84 & 4078 & 59.52 & 6264 & 53.88 & 44,142 & 65.32 & & \\
\hline$\geq 35$ & 4918 & 10.02 & 1142 & 16.67 & 1902 & 16.36 & 7962 & 11.78 & & \\
\hline Missing & 3162 & 6.44 & 513 & 7.49 & 1196 & 10.29 & 4871 & 7.21 & & \\
\hline Total & 49,097 & 100.00 & 6852 & 100.00 & 11,625 & 100.00 & 67,574 & 100.00 & & \\
\hline Mother's age at child birth (years) & & & & & & & & & 1518.61 & $<0.001$ \\
\hline$<25$ & 15,672 & 31.92 & 2092 & 30.53 & 3872 & 33.31 & 21,636 & 32.02 & & \\
\hline $25-34$ & 30,882 & 62.90 & 3985 & 58.16 & 5933 & 51.04 & 40,800 & 60.38 & & \\
\hline
\end{tabular}


Table 1 Characteristics of study participants by the number of siblings (Continued)

\begin{tabular}{|c|c|c|c|c|c|c|c|c|c|}
\hline \multirow[t]{2}{*}{ Variables } & \multicolumn{2}{|c|}{ None (only child) } & \multicolumn{2}{|l|}{ One } & \multicolumn{2}{|c|}{ Two or more } & \multicolumn{2}{|l|}{ Total } & \multirow{2}{*}{$\begin{array}{l}P \\
\text { value }^{a}\end{array}$} \\
\hline & $\mathrm{N}$ & $\%$ & $\mathrm{~N}$ & $\%$ & $\mathrm{~N}$ & $\%$ & $\mathrm{~N}$ & $\%$ & \\
\hline$\geq 35$ & 1409 & 2.87 & 571 & 8.33 & 1173 & 10.09 & 3153 & 4.67 & \\
\hline Missing & 1134 & 2.31 & 204 & 2.98 & 647 & 5.57 & 1985 & 2.94 & \\
\hline Total & 49,097 & 100.00 & 6852 & 100.00 & 11,625 & 100.00 & 67,574 & 100.00 & \\
\hline
\end{tabular}

${ }^{a} P$ Value from Chi-squared test

Table 2 Family characteristics of study participants by the number of siblings

\begin{tabular}{|c|c|c|c|c|c|c|c|c|c|c|}
\hline \multirow[t]{2}{*}{ Variables } & \multicolumn{2}{|c|}{ None (only child) } & \multicolumn{2}{|l|}{ One } & \multicolumn{2}{|c|}{ Two or more } & \multicolumn{2}{|l|}{ Total } & \multirow[t]{2}{*}{$x^{2}$} & \multirow{2}{*}{$\begin{array}{l}P \\
\text { value }^{a}\end{array}$} \\
\hline & $\bar{N}$ & $\%$ & $\bar{N}$ & $\%$ & $\bar{N}$ & $\%$ & $\bar{N}$ & $\%$ & & \\
\hline Father's weight status & & & & & & & & & 19.60 & 0.001 \\
\hline Underweight & 1594 & 3.25 & 203 & 2.96 & 288 & 2.48 & 2085 & 3.09 & & \\
\hline Normal & 30,935 & 63.01 & 4353 & 63.53 & 7394 & 63.60 & 42,682 & 63.16 & & \\
\hline Overweight & 12,667 & 25.80 & 1788 & 26.09 & 2946 & 25.34 & 17,401 & 25.75 & & \\
\hline Missing & 3901 & 7.95 & 508 & 7.41 & 997 & 8.58 & 5406 & 8.00 & & \\
\hline Total & 49,097 & 100.00 & 6852 & 100.00 & 11,625 & 100.00 & 67,574 & 100.00 & & \\
\hline Father's education level & & & & & & & & & $10,349.70$ & $<0.001$ \\
\hline Low & 8524 & 17.36 & 2416 & 35.26 & 7275 & 62.58 & 18,215 & 26.96 & & \\
\hline Middle & 22,081 & 44.97 & 2386 & 34.82 & 3137 & 26.98 & 27,604 & 40.85 & & \\
\hline High & 18,292 & 37.26 & 2023 & 29.52 & 1162 & 10.00 & 21,477 & 31.78 & & \\
\hline Missing & 200 & 0.41 & 27 & 0.39 & 51 & 0.44 & 278 & 0.41 & & \\
\hline Total & 49,097 & 100.00 & 6852 & 100.00 & 11,625 & 100.00 & 67,574 & 100.00 & & \\
\hline Mother's weight status & & & & & & & & & 509.04 & $<0.001$ \\
\hline Underweight & 5260 & 10.71 & 579 & 8.45 & 726 & 6.25 & 6565 & 9.72 & & \\
\hline Normal & 35,611 & 72.53 & 4982 & 72.71 & 8193 & 70.48 & 48,786 & 72.20 & & \\
\hline Overweight & 4794 & 9.76 & 840 & 12.26 & 1807 & 15.54 & 7441 & 11.01 & & \\
\hline Missing & 3432 & 6.99 & 451 & 6.58 & 899 & 7.73 & 4782 & 7.08 & & \\
\hline Total & 49,097 & 100.00 & 6852 & 100.00 & 11,625 & 100.00 & 67,574 & 100.00 & & \\
\hline Mother's education level & & & & & & & & & $12,096.00$ & $<0.001$ \\
\hline Low & 9842 & 20.05 & 2691 & 39.27 & 8306 & 71.45 & 20,839 & 30.84 & & \\
\hline Middle & 22,742 & 46.32 & 2511 & 36.65 & 2475 & 21.29 & 27,728 & 41.03 & & \\
\hline High & 16,450 & 33.51 & 1632 & 23.82 & 823 & 7.08 & 18,905 & 27.98 & & \\
\hline Missing & 63 & 0.13 & 18 & 0.26 & 21 & 0.18 & 102 & 0.15 & & \\
\hline Total & 49,097 & 100.00 & 6852 & 100.00 & 11,625 & 100.00 & 67,574 & 100.00 & & \\
\hline Family income & & & & & & & & & 3362.13 & $<0.001$ \\
\hline Low & 10,257 & 20.89 & 1828 & 26.68 & 5368 & 46.18 & 17,453 & 25.83 & & \\
\hline Middle & 29,251 & 59.58 & 3322 & 48.48 & 4862 & 41.82 & 37,435 & 55.40 & & \\
\hline High & 9563 & 19.48 & 1694 & 24.72 & 1388 & 11.94 & 12,645 & 18.71 & & \\
\hline Missing & 26 & 0.05 & 8 & 0.12 & 7 & 0.06 & 41 & 0.06 & & \\
\hline Total & 49,097 & 100.00 & 6852 & 100.00 & 11,625 & 100.00 & 67,574 & 100.00 & & \\
\hline Residential site & & & & & & & & & 1241.61 & $<0.001$ \\
\hline Suburban & 36,765 & 74.88 & 5567 & 81.25 & 10,421 & 89.64 & 52,753 & 78.07 & & \\
\hline Urban & 12,313 & 25.08 & 1284 & 18.74 & 1200 & 10.32 & 14,797 & 21.90 & & \\
\hline Missing & 19 & 0.04 & 1 & 0.01 & 4 & 0.03 & 24 & 0.04 & & \\
\hline Total & 49,097 & 100.00 & 6852 & 100.00 & 11,625 & 100.00 & 67,574 & 100.00 & & \\
\hline
\end{tabular}


Table 3 Distribution of prevalence of thinness by sibship size or structure

\begin{tabular}{|c|c|c|c|c|c|c|c|c|c|}
\hline \multirow[t]{2}{*}{ Variables } & \multirow{2}{*}{$\begin{array}{l}\text { Total sample } \\
\text { N }\end{array}$} & \multicolumn{2}{|c|}{ Grade 1 thinness } & \multicolumn{2}{|c|}{ Grade 2 thinness } & \multicolumn{2}{|c|}{ Grade 3 thinness } & \multicolumn{2}{|c|}{ Total thinness } \\
\hline & & $\mathrm{N}$ & $\%$ & $\mathrm{~N}$ & $\%$ & $\mathrm{~N}$ & $\%$ & $\mathrm{~N}$ & $\%$ \\
\hline \multicolumn{10}{|l|}{ Number of siblings } \\
\hline None (only child) & 49,097 & 4884 & 9.95 & 1469 & 2.99 & 993 & 2.02 & 7346 & 14.96 \\
\hline One & 6852 & 784 & 11.44 & 258 & 3.77 & 204 & 2.98 & 1246 & 18.18 \\
\hline Two or more & 11,625 & 1128 & 9.70 & 423 & 3.64 & 478 & 4.11 & 2029 & 17.45 \\
\hline Total & 67,574 & 6796 & 10.06 & 2150 & 3.18 & 1675 & 2.48 & 10,621 & 15.72 \\
\hline \multicolumn{10}{|l|}{ Birth order } \\
\hline Only child & 49,097 & 4884 & 9.95 & 1469 & 2.99 & 993 & 2.02 & 7346 & 14.96 \\
\hline Oldest child & 7941 & 855 & 10.77 & 285 & 3.59 & 268 & 3.37 & 1408 & 17.73 \\
\hline Middle & 6696 & 638 & 9.53 & 240 & 3.58 & 268 & 4.00 & 1146 & 17.11 \\
\hline Youngest child & 3162 & 359 & 11.35 & 142 & 4.49 & 116 & 3.67 & 617 & 19.51 \\
\hline Missing & 678 & 60 & 8.85 & 14 & 2.06 & 30 & 4.42 & 104 & 15.34 \\
\hline Total & 67,574 & 6796 & 10.06 & 2150 & 3.18 & 1675 & 2.48 & 10,621 & 15.72 \\
\hline \multicolumn{10}{|l|}{ Number of younger siblings } \\
\hline None (only child) & 49,097 & 4884 & 9.95 & 1469 & 2.99 & 993 & 2.02 & 7346 & 14.96 \\
\hline One (oldest child) & 3691 & 421 & 11.41 & 119 & 3.22 & 90 & 2.44 & 630 & 17.07 \\
\hline Two or more (oldest child) & 4250 & 434 & 10.21 & 166 & 3.91 & 178 & 4.19 & 778 & 18.31 \\
\hline Total & 57,038 & 5739 & 10.06 & 1754 & 3.08 & 1261 & 2.21 & 8754 & 15.35 \\
\hline \multicolumn{10}{|l|}{ Number of older siblings } \\
\hline None (only child) & 49,097 & 4884 & 9.95 & 1469 & 2.99 & 993 & 2.02 & 7346 & 14.96 \\
\hline One (youngest child) & 2968 & 342 & 11.52 & 134 & 4.51 & 107 & 3.61 & 583 & 19.64 \\
\hline Two or more (youngest child) & 194 & 17 & 8.76 & 8 & 4.12 & 9 & 4.64 & 34 & 17.53 \\
\hline Total & 52,259 & 5243 & 10.03 & 1611 & 3.08 & 1109 & 2.12 & 7963 & 15.24 \\
\hline
\end{tabular}

In the only-child, one-sibling, and two-or-more-siblings groups of boys (Fig. 2), the prevalence of grade 2 thinness $(2.54,3.24,3.40 \%$, respectively) and grade 3 thinness (1.76, $2.66,3.57 \%$, respectively) was highest in the two-or-moresiblings group, and the prevalence of grade 1 thinness (8.71, 9.78, 8.31\%, respectively) was highest in the onesibling group. As for girls (Fig. 3), the prevalence of grade 1 thinness $(11.38,13.14,11.20 \%$, respectively) and grade 3 thinness $(2.33,3.30,4.70 \%$, respectively) was highest in the one-sibling and two-or-more-siblings group, respectively, but not in the only-child group. This was similar with the prevalence for boys, except that the prevalence of grade 2 thinness (3.52, 4.30, 3.89\%, respectively) was highest for boys in the one-sibling group. Overall, girls were more likely to be thin than boys.

Crude and adjusted ORs of the number of siblings, birth order, and number of younger or older siblings for thinness among boys and girls are presented in Tables 4 and 5 , respectively. Among boys, in model III, children with two or more siblings were more likely to suffer from grade 2 (OR = $1.29,95 \% \mathrm{CI} 1.02,1.64)$ and grade 3 thinness $(\mathrm{OR}=1.60$, $95 \%$ CI 1.07, 2.40) compared with only child; and youngest children faced a higher risk of grade $2(\mathrm{OR}=1.44,95 \% \mathrm{CI}$ $1.09,1.90)$ and grade 3 thinness $(\mathrm{OR}=1.53,95 \% \mathrm{CI} 1.01$,
2.33). Although there was no significant relationship with thinness for a larger number of younger or older siblings, in two-child families, the younger child had a higher OR for grade 3 thinness $(\mathrm{OR}=1.57,95 \% \mathrm{CI} 1.18,2.09)$, and in three-or-more-children families, the oldest child faced a higher risk of grade 2 thinness $(\mathrm{OR}=2.00,95 \%$ CI 1.47 , 1.72). Among girls, in model III, children with one sibling were more likely to suffer from grade 1 thinness $(\mathrm{OR}=$ 1.22, 95\% CI 1.05, 1.42); and the oldest child, middle child, and youngest child faced a higher risk of grade $1(\mathrm{OR}=$ $1.42,95 \% \mathrm{CI} 1.09,1.84)$, grade $2(\mathrm{OR}=1.26,95 \% \mathrm{CI} 1.03$, 1.54 ), and grade 1 thinness ( $\mathrm{OR}=1.87,95 \% \mathrm{CI} 1.21,2.88$ ), respectively. In families with children who had siblings, the youngest child with one older sibling had a higher risk of grade $1(\mathrm{OR}=1.38,95 \% \mathrm{CI} 1.05,1.81)$ and grade 3 thinness (OR $=1.84,95 \%$ CI 1.15, 2.93).

Combining with result of the analysis of the association between sibship size or structure and thinness in the total samples (See Supplementary Table A1, Additional File 1) and in the samples of different genders (Tables 4 and 5) and results of sex-interaction in the multinomial logistic regression models (See Supplementary Table A2, Additional File 1), we found that those children with siblings or having a high birth order faced a higher risk of thinness, and youngest brothers 


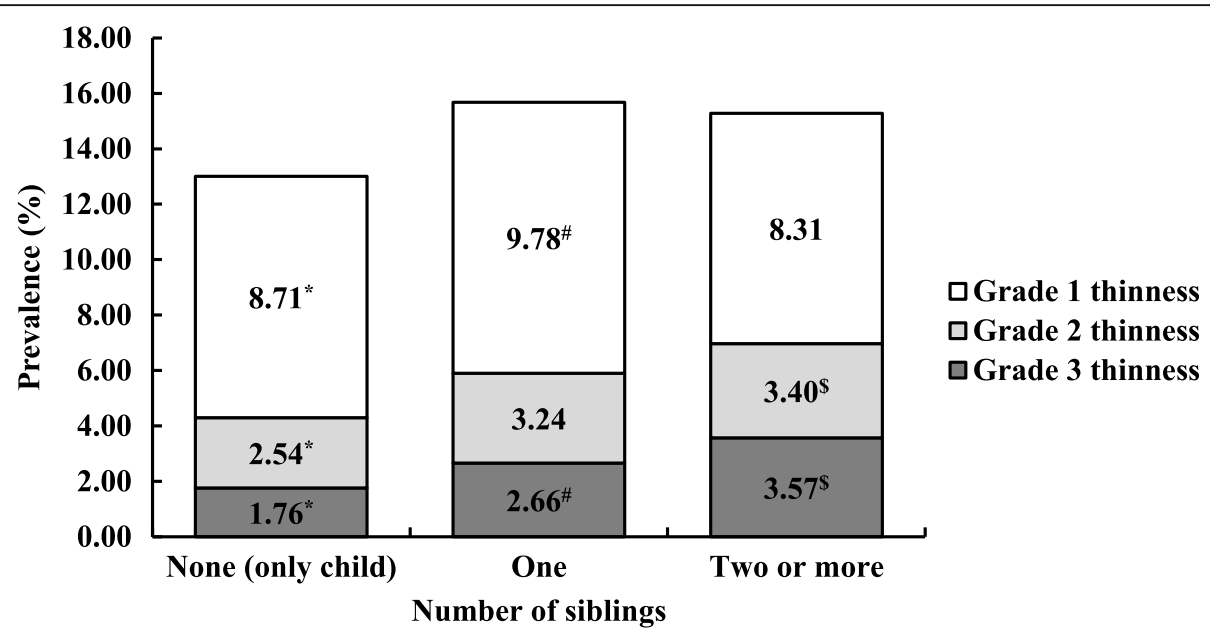

Fig. 2 Distribution of the prevalence of grades 1, 2, and 3 thinness in boys. " Statistically significant difference in prevalence between 0 (only child) and 1 sibling ( $x 2$ test): $p<0.05$; " Statistically significant difference in prevalence between 1 and $\geq 2$ siblings ( $x 2$ test): $p<0.05$; ${ }^{\$}$ Statistically significant difference in prevalence between 0 (only child) and $\geq 2$ siblings ( $X 2$ test): $p<0.05$.

and sisters were at greater risk of thinness in families with two children. Notably, this difference was in families with three or more children, and the oldest brothers and the youngest sisters tended to be more prone to thinness. These associations did not change in children with different gender, showing that there was not interaction effect between sibship size or structure and sex on thinness.

\section{Discussion}

Our results showed that sibling children had a higher OR for thinness compared with only children. Few studies have reported that many siblings are a risk factor for thinness. However, one study found that having siblings increased ORs for childhood underweight, especially when a malnourished sibling lived within the household [29]. Other studies indicated that having a larger number of siblings was associated with a more significant decrease in BMI $[18,31]$. One study, however, reported that there was no association between the number of siblings and thinness [24], whereas another study found that thinness was more common in girls than in boys [23]. One possible explanation is the effect of behavior and interaction among family members. On the one hand, upbringing and available resources for nutrition are different for children with different numbers of siblings, which may affect childhood weight status. A previous study reported that children with siblings faced a higher malnutrition risk [32]. Moreover, the nutritive

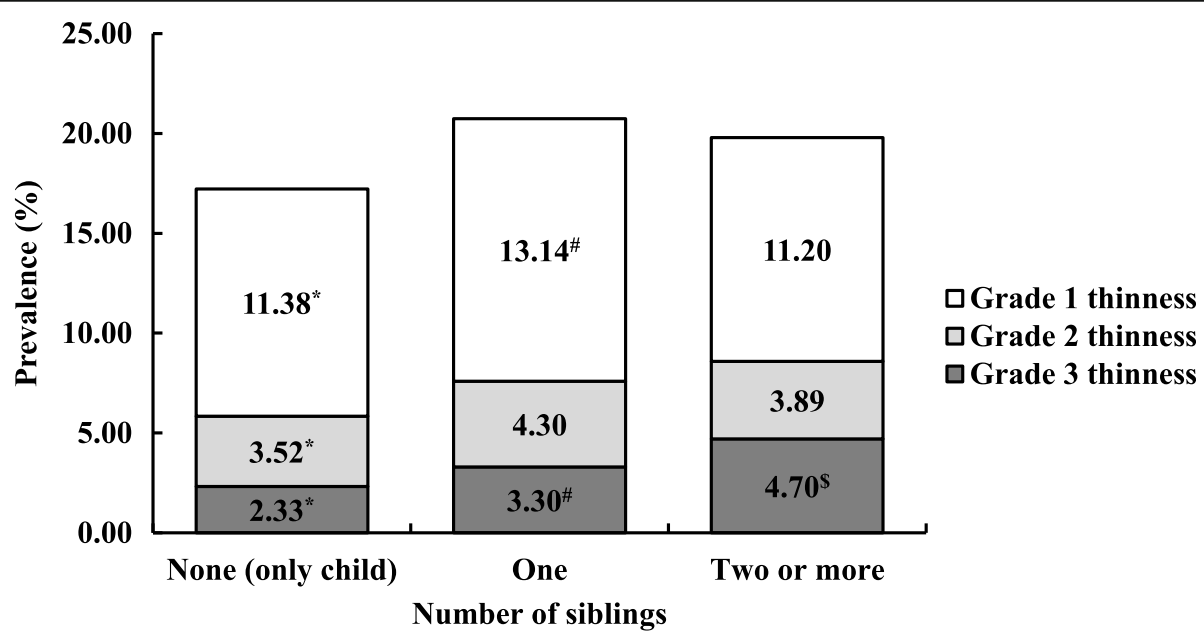

Fig. 3 Distribution of the prevalence of grades 1, 2, and 3 thinness in girls. ${ }^{*}$ Statistically significant difference in prevalence between 0 (only child) and 1 sibling ( $\times 2$ test): $p<0.05$; ${ }^{\#}$ Statistically significant difference in prevalence between 1 and $\geq 2$ siblings ( $\chi 2$ test): $p<0.05$; ${ }^{\$}$ Statistically significant difference in prevalence between 0 (only child) and $\geq 2$ siblings ( $x 2$ test): $p<0.05$ 
Table 4 Multinomial logistical regression of sibship size or structure for thinness among boys

\begin{tabular}{|c|c|c|c|c|c|c|c|c|c|c|}
\hline & \multirow{2}{*}{$\begin{array}{l}\text { Total } \\
\mathrm{N}\end{array}$} & \multicolumn{3}{|c|}{ Grade 1 thinness } & \multicolumn{3}{|c|}{ Grade 2 thinness } & \multicolumn{3}{|c|}{ Grade 3 thinness } \\
\hline & & Model $I^{a}$ & Model $\|^{b}$ & Model III & Model I & Model $\|^{\mathrm{b}}$ & Model III & Model $I^{a}$ & Model $\|^{b}$ & Model III \\
\hline \multicolumn{11}{|l|}{ Number of siblings } \\
\hline None (only child) & $\begin{array}{l}26 \\
351\end{array}$ & 1.00 (Ref) & 1.00 (Ref) & 1.00 (Ref) & 1.00 (Ref) & 1.00 (Ref) & 1.00 (Ref) & 1.00 (Ref) & 1.00 (Ref) & 1.00 (Ref) \\
\hline One & 3457 & $\begin{array}{l}1.13(1.03 \\
1.24)^{*}\end{array}$ & $\begin{array}{l}1.11(1.00 \\
1.24)\end{array}$ & $\begin{array}{l}1.10(0.98 \\
1.24)\end{array}$ & $\begin{array}{l}1.27(1.02 \\
1.60)^{*}\end{array}$ & $\begin{array}{l}1.34(1.07 \\
1.69)^{*}\end{array}$ & $\begin{array}{l}1.28(1.00 \\
1.63)\end{array}$ & $\begin{array}{l}1.48(1.08, \\
2.03)^{*}\end{array}$ & $\begin{array}{l}1.38(0.96 \\
1.99)\end{array}$ & $\begin{array}{l}1.31(0.89, \\
1.92)\end{array}$ \\
\hline Two or more & 6027 & $\begin{array}{l}1.00(0.88, \\
1.12)\end{array}$ & $\begin{array}{l}0.96(0.83 \\
1.12)\end{array}$ & $\begin{array}{l}0.96(0.80 \\
1.16)\end{array}$ & $\begin{array}{l}1.41(1.19 \\
1.67)^{*}\end{array}$ & $\begin{array}{l}1.46(1.17 \\
1.82)^{*}\end{array}$ & $\begin{array}{l}1.29(1.02 \\
1.64)^{*}\end{array}$ & $\begin{array}{l}2.16(1.61 \\
2.90)^{*}\end{array}$ & $\begin{array}{l}1.88(1.30 \\
2.72)^{*}\end{array}$ & $\begin{array}{l}1.60(1.07, \\
2.40)^{*}\end{array}$ \\
\hline \multicolumn{11}{|l|}{ Birth order } \\
\hline Only child & $\begin{array}{l}26 \\
351\end{array}$ & 1.00 (Ref) & 1.00 (Ref) & 1.00 (Ref) & 1.00 (Ref) & 1.00 (Ref) & 1.00 (Ref) & 1.00 (Ref) & 1.00 (Ref) & 1.00 (Ref) \\
\hline Oldest child & 3331 & $\begin{array}{l}0.95(0.81 \\
1.12)\end{array}$ & $\begin{array}{l}0.91(0.75 \\
1.10)\end{array}$ & $\begin{array}{l}0.89(0.73 \\
1.08)\end{array}$ & $\begin{array}{l}1.33(1.07 \\
1.64)^{*}\end{array}$ & $\begin{array}{l}1.28(1.02 \\
1.61)^{*}\end{array}$ & $\begin{array}{l}1.32(1.03 \\
1.70)^{*}\end{array}$ & $\begin{array}{l}1.57(1.20 \\
2.04)^{*}\end{array}$ & $\begin{array}{l}1.34(0.99 \\
1.82)\end{array}$ & $\begin{array}{l}1.26(0.90, \\
1.77)\end{array}$ \\
\hline Middle child & 3923 & $\begin{array}{l}1.09(0.92 \\
1.30)\end{array}$ & $\begin{array}{l}1.08(0.86 \\
1.35)\end{array}$ & $\begin{array}{l}1.11(0.86 \\
1.44)\end{array}$ & $\begin{array}{l}1.36(1.10 \\
1.68)^{*}\end{array}$ & $\begin{array}{l}1.45(1.08, \\
1.93)^{*}\end{array}$ & $\begin{array}{l}1.20(0.93 \\
1.56)\end{array}$ & $\begin{array}{l}2.14(1.57 \\
2.94)^{*}\end{array}$ & $\begin{array}{l}1.97(1.29 \\
3.02)^{*}\end{array}$ & $\begin{array}{l}1.61(0.98, \\
2.64)\end{array}$ \\
\hline Youngest child & 1869 & $\begin{array}{l}1.13(0.96 \\
1.32)\end{array}$ & $\begin{array}{l}1.16(0.94 \\
1.44)\end{array}$ & $\begin{array}{l}1.17(0.95 \\
1.45)\end{array}$ & $\begin{array}{l}1.54(1.14 \\
2.08)^{*}\end{array}$ & $\begin{array}{l}1.73(1.30 \\
2.28)^{*}\end{array}$ & $\begin{array}{l}1.44(1.09 \\
1.90)^{*}\end{array}$ & $\begin{array}{l}1.82(1.28 \\
2.59)^{*}\end{array}$ & $\begin{array}{l}1.74(1.20 \\
2.52)^{*}\end{array}$ & $\begin{array}{l}1.53(1.01 \\
2.33)^{*}\end{array}$ \\
\hline \multicolumn{11}{|c|}{ Number of younger siblings } \\
\hline None (only child) & $\begin{array}{l}26 \\
351\end{array}$ & 1.00 (Ref) & 1.00 (Ref) & 1.00 (Ref) & 1.00 (Ref) & 1.00 (Ref) & 1.00 (Ref) & 1.00 (Ref) & 1.00 (Ref) & 1.00 (Ref) \\
\hline One (oldest child) & 1614 & $\begin{array}{l}1.09(0.86 \\
1.37)\end{array}$ & $\begin{array}{l}1.04(0.79 \\
1.38)\end{array}$ & $\begin{array}{l}1.03(0.77 \\
1.39)\end{array}$ & $\begin{array}{l}0.94(0.69 \\
1.28)\end{array}$ & $\begin{array}{l}0.91(0.64 \\
1.28)\end{array}$ & $\begin{array}{l}1.03(0.73 \\
1.45)\end{array}$ & $\begin{array}{l}1.13(0.71 \\
1.81)\end{array}$ & $\begin{array}{l}1.04(0.64, \\
1.68)\end{array}$ & $\begin{array}{l}1.03(0.63, \\
1.68)\end{array}$ \\
\hline $\begin{array}{l}\text { Two or more (oldest } \\
\text { child) }\end{array}$ & 1717 & $\begin{array}{l}0.81(0.61 \\
1.08)\end{array}$ & $\begin{array}{l}0.78(0.60 \\
1.02)\end{array}$ & $\begin{array}{l}0.74(0.55 \\
0.99)\end{array}$ & $\begin{array}{l}1.70(1.30 \\
2.23)^{*}\end{array}$ & $\begin{array}{l}1.64(1.20 \\
2.23)^{*}\end{array}$ & $\begin{array}{l}1.59(1.12 \\
2.28)^{*}\end{array}$ & $\begin{array}{l}2.00(1.47 \\
2.72)^{*}\end{array}$ & $\begin{array}{l}1.60(1.06 \\
2.41)^{*}\end{array}$ & $\begin{array}{l}1.44(0.90, \\
2.29)\end{array}$ \\
\hline \multicolumn{11}{|l|}{ Number of older siblings } \\
\hline None (only child) & $\begin{array}{l}26 \\
351\end{array}$ & 1.00 (Ref) & 1.00 (Ref) & 1.00 (Ref) & 1.00 (Ref) & 1.00 (Ref) & 1.00 (Ref) & 1.00 (Ref) & 1.00 (Ref) & 1.00 (Ref) \\
\hline $\begin{array}{l}\text { One (youngest } \\
\text { child) }\end{array}$ & 1738 & $\begin{array}{l}1.17(0.96, \\
1.42)\end{array}$ & $\begin{array}{l}1.20(0.93 \\
1.56)\end{array}$ & $\begin{array}{l}1.19(0.92, \\
1.55)\end{array}$ & $\begin{array}{l}1.60(1.18 \\
2.16)^{*}\end{array}$ & $\begin{array}{l}1.82(1.35 \\
2.46)^{*}\end{array}$ & $\begin{array}{l}1.57(1.18 \\
2.09)^{*}\end{array}$ & $\begin{array}{l}1.77(1.23 \\
2.56)^{*}\end{array}$ & $\begin{array}{l}1.70(1.10 \\
2.62)^{*}\end{array}$ & $\begin{array}{l}1.52(0.91, \\
2.53)\end{array}$ \\
\hline $\begin{array}{l}\text { Two or more } \\
\text { (youngest child) }\end{array}$ & 131 & $\begin{array}{l}0.61(0.14, \\
2.61)\end{array}$ & $\begin{array}{l}0.66(0.13 \\
3.24)\end{array}$ & $\begin{array}{l}0.74(0.14 \\
3.86)\end{array}$ & $\begin{array}{l}0.81(0.29 \\
2.26)\end{array}$ & $\begin{array}{l}0.89(0.20 \\
3.98)\end{array}$ & $\begin{array}{l}0.93(0.22 \\
4.01)\end{array}$ & $\begin{array}{l}2.53(0.82 \\
7.77)\end{array}$ & $\begin{array}{l}2.91(0.73, \\
11.63)\end{array}$ & $\begin{array}{l}2.47 \text { (0.66, } \\
9.26)\end{array}$ \\
\hline
\end{tabular}

Ref: reference category

a Model I: adjusted for age

${ }^{b}$ Model II: adjusted for age and childhood characteristics (birthweight, feeding patterns, parental age at child birth, workday TV time, internet use time, snacking frequency)

c Model III: adjusted for age, childhood characteristics and family characteristics (parental weight status, parental educational level, family income and residential site)

${ }^{*} p<0.05$

value of diets for each child in small families was higher than that in large families, and children with siblings had significantly lower protein intake than only children [32]. It also has been reported that higher protein intake is associated with a lower risk of thinness [33]. On the other hand, additional sibling(s) enhanced interactions between children, and previous studies have identified a relationship between physical activity and siblings [34]. Moreover, children with siblings spent more time engaged in afterschool sports or household chores than only children [18]. In this study, when we adjusted sedentary behavior, including workday TV time and Internet use time, the positive association of the number of siblings with childhood thinness remained.
Regarding birth order, a higher birth order has been reported to significantly increase ORs for undernutrition [20-22, 35], which is consistent with our results. In contrast, some studies have not found a relationship between BMI or thinness and birth order [24,31]. Thus, the association of birth order with childhood thinness remains unclear; however, differences in fetal nutrition and changes in some factors related to growth development in early life may explain this outcome. With increasing pregnancies and the expansion of household size, child- and familyrelated factors may have changed, such as birthweight and prenatal weight. The relationship between birth order and thinness, however, remained after adjusting for these factors. Thus, factors other than variates in the present study 


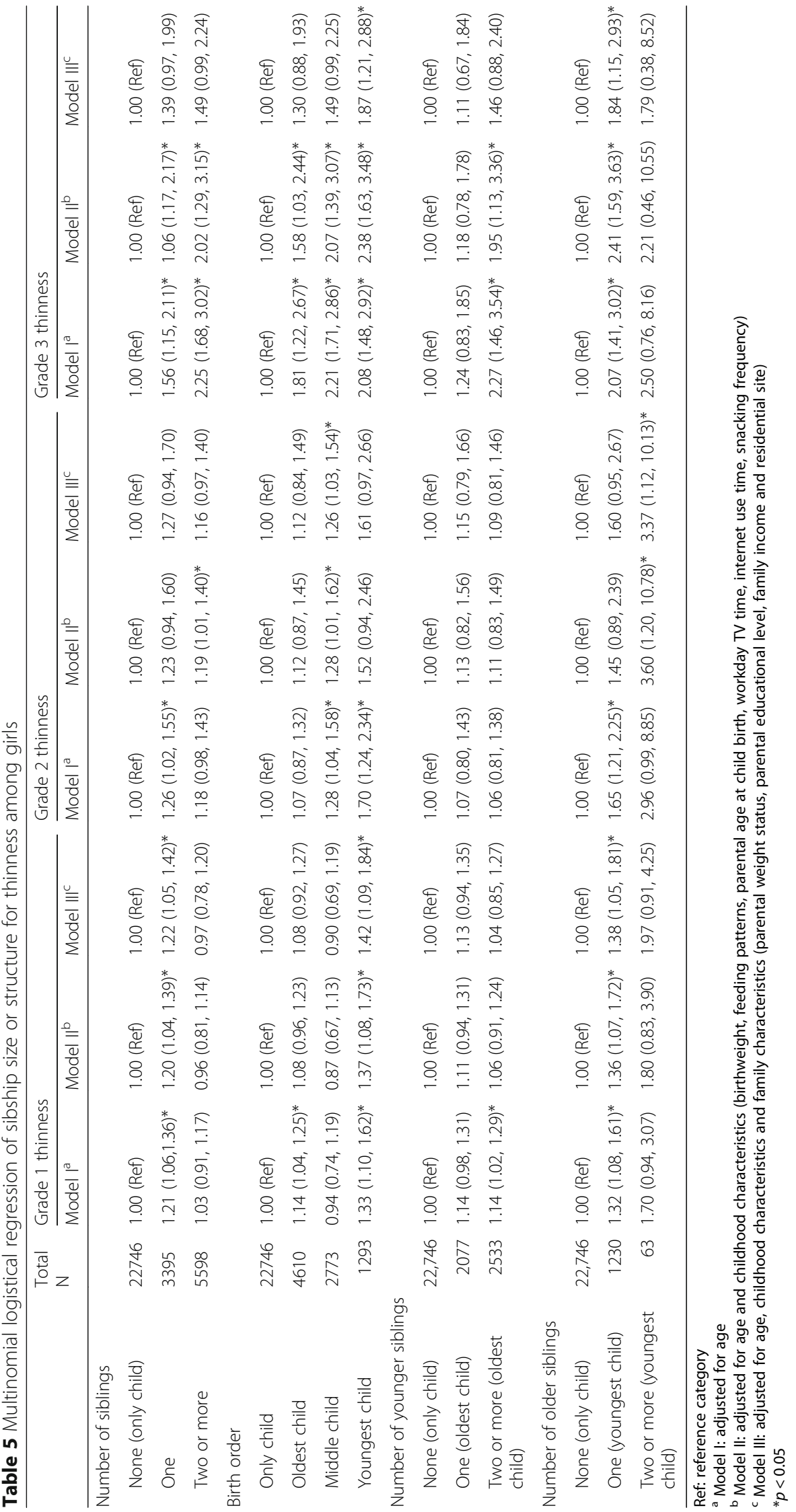


could be associated with the relationship between birth order and thinness. In addition, one study reported that firstborn children had lower birthweights than their younger siblings, yet they tended to be more sensitive to factors that could encourage growth [36].

In our study, there was no relationship between a greater number of younger or older siblings and thinness. In two-child families, however, younger children faced a higher risk of thinness, which may have been the result of being at a competitive disadvantage compared with their older siblings. Additionally, these children appeared to have spent more time engaging in physical activity as a result of imitating the behaviors of their older siblings [37].

Children with siblings or with a higher birth order were more likely to be thin in both boys and girls. The results showed, however, that as a family's resourcerelevant confounding factors adjusted the logistics model, the relationship between two or more siblings and thinness did not exist in girls but remained in boys. Therefore, girls may get less nutritional resources than boys in families with three or more children. Currently, there is no biological mechanism for the influence of family structure on children's weight status. Most studies have discussed the family structure, which may lead to differences in children's lifestyle, mainly including nutritional access and family interactions. Future studies related to family structure and physical development should pay attention to the availability of nutrition and physical and emotion interaction with parents and siblings among preschool and school-age children.

The strengths of our study are as follows. First, we evaluated the relationship between the number of siblings and birth order and childhood thinness. To our knowledge, no related study has been carried out in China. Second, the large sample size and multistage cluster random sampling employed ensured the use of representative data. Therefore, we had the ability to examine the influence of number of siblings and birth order on childhood thinness. Finally, we examined the relationship of the number of older or younger siblings with thinness, which previously had not been studied. This study also had some limitations. Shanghai has a high socioeconomic level; thus, samples from this study did not represent China as a whole. In addition, the implementation of the two-child policy may change the median birth interval of Chinese children, and the length of the birth interval has an impact on the status of a child's weight [29]. We note that this information was not available for our study. Although we did include sedentary behaviors factors, including workday TV time and Internet use time, as well as dietary factors like snacking frequency as confounding factors into the adjusted logistic regression model, other potential confounding factors, including physical activity, nutrition intake, sleeping habits, emotional assessment, and parent-child relationship, that had an important effect on childhood status were not adjusted in this study. In fact, a recent study reported that the engagement level of family members was positively associated with a child's diet quality [38]. Additionally, the collection of height and weight data of children according to self-reports may have affected the definition of weight status to some extent. Our findings may apply only to children between 3 and 12 years of age, and therefore, we cannot discern whether the number of siblings or birth order will have lasting effects on a child's future health.

\section{Conclusions}

In general, as the number of siblings and birth order increased, a child's risk of thinness also increased. In twochild families, the youngest child was more likely to be thin. In addition to helping researchers better identify children at risk of thinness, our findings also provide a reference for the implementation and social policy formulation of child thinness intervention. On basis of these findings, when formulating policies for the allocation of social resources, developing countries should be more inclined toward families with two or more children to improve access to nutrition among these children, especially those in the lower level economic regions. At the same time, in terms of parenting styles, methods should be advocated that more reasonably plan nutrition intake and interaction among children with different birth orders.

\section{Supplementary information}

Supplementary information accompanies this paper at https://doi.org/10. 1186/s12887-020-02261-z.

Additional file 1: Table A1. Multinomial logistical regression of sibship size or structure for thinness. Table A2. Interaction effect between sibship size or structure and sex for thinness by using multinomial logistical regression.

\section{Abbreviations \\ BMI: Body mass index; SD: Standard deviations; OR: Odds ratio; $\mathrm{Cl}$ : Confidence interval}

\section{Acknowledgments \\ We thank the children, parents, and teachers who participated in this} research for their help and cooperation.

\section{Authors' contributions}

T.Y. and C.C. contributed equally to this work. X.J., Z.J., and S.L. designed the study; Z.J., Y.Y., Y.J., L.H., X.Y., H.H., H.M., and F.J. performed the research; T.Y., C.C., and S.L. performed data analyses, interpreted the results, and drafted the manuscript; H.H. and S.L. were major contributors in revising the manuscript; and S.L. had primary responsibility for the final content. All authors read and approved the final manuscript.

\section{Funding}

This study was supported by the Shanghai Municipal Commission of Health and Family Planning: Shanghai Municipal Enhancing Public Health 3-Year Program (2011-2013) [11PH1951202], National Natural Science Foundation of China [81872637, 81602868], Shanghai Municipal Commission of Health and 
Family Planning [201840324], Medical and Engineering Cooperation Project of Shanghai Jiao Tong University [YG2017ZD15], Project of Shanghai Children's Health Service Capacity Construction [GDEK201708], National Human Genetic Resources Sharing Service Platform [2005DKA21300], Science and Technology Development Program of Pudong Shanghai New District [PKJ2017-Y01], and Shanghai Professional and Technical Services Platform [18DZ2294100].

\section{Availability of data and materials}

All data generated or analysed during this study are included in this published article and its supplementary information files.

\section{Ethics approval and consent to participate}

This study was conducted according to the guidelines in the World Medical Association (2000) Declaration of Helsinki: Ethical Principles for Medical Research Involving Human Subjects (https:/www.wma.net/what-we-do/ medical-ethics/declaration-of-helsinki/) and the Guidelines for the Ethical Conduct of Medical Research Involving Children, revised in 2000 by the Royal College of Pediatrics and Child Health: Ethics Advisory Committee (Arch Dis Child 2000, 82, 177-182). All procedures involving human subjects were approved by the Institutional Review Boards of the Shanghai Municipal Commission of Health and Family Planning. Verbal informed consent was obtained from all participants, and witnessed and formally recorded.

\section{Consent for publication}

Not applicable.

\section{Competing interests}

The authors declare that they have no competing interests.

\section{Author details}

${ }^{1}$ School of Public Health, Shanghai Jiao Tong University School of Medicine, Shanghai, China. ${ }^{2}$ Pediatric Translational Medicine Institute, Shanghai Children's Medical Center, Shanghai Jiao Tong University School of Medicine, 1678 Dongfang Road, Shanghai 200127, China. ${ }^{3}$ Shanghai Key Laboratory of Children's Environmental Health, Xinhua Hospital, Shanghai Jiao Tong University School of Medicine, 1665 Kongjiang Road, Shanghai 200092, China. ${ }^{4}$ Department of Developmental and Behavioral Pediatrics, Shanghai Children's Medical Center, Shanghai Jiao Tong University School of Medicine, Shanghai, China. ${ }^{5}$ Department of Clinical Nutrition, Shanghai Children's Medical Center, Shanghai Jiao Tong University School of Medicine, Shanghai, China. ${ }^{6}$ Department of Data Science, School of Population Health, University of Mississippi Medical Center, Jackson, Mississippi, USA. ${ }^{7}$ Department of Developmental and Behavioral Pediatrics, Shanghai Pubin Children Hospital, Shanghai, China.

Received: 5 September 2019 Accepted: 28 July 2020

Published online: 05 August 2020

\section{References}

1. Luby JL, Belden A, Harms MP, et al. Preschool is a sensitive period for the influence of maternal support on the trajectory of hippocampal development. Proc Natl Acad Sci U S A. 2016;113:5742-7.

2. Parkes A, Sweeting H, Wight D. Early childhood precursors and school age correlates of different Internalising problem trajectories among young children. J Abnorm Child Psychol. 2016;44:1333-46.

3. Aly R, Viswanathan B, Mangroo G, et al. Trends in obesity, overweight, and thinness in children in the Seychelles between 1998 and 2016. Obesity (Silver Spring). 2018;26:606-12.

4. Kist-van Holthe J, Blom T, Melchers L, et al. Stabilization of the obesity epidemic and increasing thinness in children in Caribbean Bonaire. BMC Pediatr. 2018;18:168.

5. de Wilde JA, Zandbergen-Harlaar S, van Buuren S, et al. Trends in body mass index distribution and prevalence of thinness, overweight and obesity in two cohorts of Surinamese South Asian children in The Netherlands. Arch Dis Child. 2013;98:280-5.

6. Fang $Y$, Zhao L, Yu D, et al. Prevalence of stunting and wasting among children and adolescents aged 6 to 17 years in 2010-2012 in China. Wei Sheng Yan Jiu. 2018;47:27-31 (in Chinese).
7. Chen $C$, Jin Z, Yang $Y$, et al. Prevalence of grade 1, 2 and 3 thinness is associated with lower socio-economic status in children in Shanghai, China. Public Health Nutr. 2016;19:2002-10.

8. Prendergast AJ, Humphrey JH. The stunting syndrome in developing countries. Paediatr Int Child Health. 2014;34:250-65.

9. Li C, Zhu N, Zeng L, et al. Effect of prenatal and postnatal malnutrition on intellectual functioning in early school-aged children in rural western China. Medicine (Baltimore). 2016;95:e4161-e61.

10. Hock RS, Bryce CP, Fischer L, et al. Childhood malnutrition and maltreatment are linked with personality disorder symptoms in adulthood: results from a Barbados lifespan cohort. Psychiatry Res. 2018;269:301-8.

11. Roberts E, Warren JR. Family structure and childhood anthropometry in Saint Paul, Minnesota in 1918. Hist Fam. 2017;22:258-90.

12. Assefa $H$, Belachew T, Negash L. Socio-demographic factors associated with underweight and stunting among adolescents in Ethiopia. Pan Afr Med J. 2015;20:252.

13. Chen AY, Escarce JJ. Family structure and childhood obesity, early childhood longitudinal study - kindergarten cohort. Prev Chronic Dis. 2010;7:A50.

14. Cheng TO. One-child policy and increased mechanization are additional risk factors for increased coronary artery disease in modern China. Int J Cardiol. 2005;100:333.

15. Downey DB. Number of siblings and intellectual development. The resource dilution explanation. Am Psychol. 2001;56:497-504.

16. Mosli RH, Miller AL, Peterson KE, et al. Birth order and sibship composition as predictors of overweight or obesity among low-income 4- to 8-year-old children. Pediatr Obes. 2016;11:40-6.

17. Ochiai $H$, Shirasawa T, Ohtsu T, et al. Number of siblings, birth order, and childhood overweight: a population-based cross-sectional study in Japan. BMC Public Health. 2012;12:766.

18. Li M, Xue H, Wang W, et al. Increased obesity risks for being an only child in China: findings from a nationally representative study of 19,487 children. Public Health. 2017;153:44-51.

19. Haugaard $L K$, Ajslev TA, Zimmermann $E$, et al. Being an only or last-born child increases later risk of obesity. PLoS One. 2013;8:e56357.

20. Tigga PL, Sen J, Mondal N. Association of some socio-economic and sociodemographic variables with wasting among pre-school children of North Bengal, India. Ethiop J Health Sci. 2015;25:63-72.

21. Galgamuwa LS, Iddawela D, Dharmaratne SD, et al. Nutritional status and correlated socio-economic factors among preschool and school children in plantation communities, Sri Lanka. BMC Public Health. 2017;17:377.

22. Nahar B, Ahmed T, Brown KH, et al. Risk factors associated with severe underweight among young children reporting to a diarrhoea treatment facility in Bangladesh. J Health Popul Nutr. 2010;28:476-83.

23. Raj A, McDougal LP, Silverman JG. Gendered effects of siblings on child malnutrition in South Asia: cross-sectional analysis of demographic and health surveys from Bangladesh, India, and Nepal. Matern Child Health J. 2015:19:217-26.

24. Jahanihashemi H, Noroozi M, Zavoshy R, et al. Malnutrition and birth related determinants among children in Qazvin, Iran. Eur J Public Health. 2017;27:559-62.

25. Ouyang Y. China relaxes its one-child policy. Lancet (London, England). 2013;382:e28.

26. Song J. Only child and families with only child in China. Popu Res; 2005;29: 16-24. (in Chinese).

27. Cole TJ, Flegal KM, Nicholls D, et al. Body mass index cut offs to define thinness in children and adolescents: international survey. BMJ Clin Res. 2007;335:194.

28. Cole TJ, Bellizzi MC, Flegal KM, et al. Establishing a standard definition for child overweight and obesity worldwide: international survey. BMJ Clin Res. 2000;320:1240-3.

29. Singh A, Arokiasamy P, Pradhan J, et al. Sibling- and family-level clustering of underweight children in northern India. J Biosoc Sci. 2017;49:348-63.

30. Tao Y. Middle income and middle income group in Shanghai. J Soc Sci. 2006;9:91-9 (in Chinese).

31. de Oliveira MF, Assunção MCF, Schäfer AA, et al. The influence of birth order and number of siblings on adolescent body composition: evidence from a Brazilian birth cohort study. Br J Nutr. 2015;114:118-25.

32. Migunova YV, Sadykov RM. Nutrition of children in modern Russian family: social and economic aspect. Vopr Pitan. 2018;87:103-7.

33. Kinyoki DK, Kandala N-B, Manda SO, et al. Assessing comorbidity and correlates of wasting and stunting among children in Somalia using crosssectional household surveys: 2007 to 2010. BMJ Open. 2016;6:e009854. 
34. Deforche B, De Bourdeaudhuij I, Tanghe A, et al. Changes in physical activity and psychosocial determinants of physical activity in children and adolescents treated for obesity. Patient Educ Couns. 2004;55:407-15.

35. El Kishawi RR, Soo KL, Abed YA, et al. Prevalence and associated factors for dual form of malnutrition in mother-child pairs at the same household in the Gaza Strip-Palestine. PLoS One. 2016;11:e0151494.

36. Wells JCK, Hallal PC, Reichert FF, et al. Associations of birth order with early growth and adolescent height, body composition, and blood pressure: prospective birth cohort from Brazil. Am J Epidemiol. 2011;174:1028-35.

37. Ylitalo KR, Bridges CN, Gutierrez M, et al. Sibship, physical activity, and sedentary behavior: a longitudinal, observational study among Mexicanheritage sibling dyads. BMC Public Health. 2019;19:191.

38. Vanhelst J, Beghin L, Drumez E, et al. Adolescents' diet quality in relation to their relatives' and peers' diet engagement and encouragement: the Healthy Lifestyle in Europe by Nutrition in Adolescence (HELENA) study. Public Health Nutr. 2018;21:3192-201.

\section{Publisher's Note}

Springer Nature remains neutral with regard to jurisdictional claims in published maps and institutional affiliations.

Ready to submit your research? Choose BMC and benefit from:

- fast, convenient online submission

- thorough peer review by experienced researchers in your field

- rapid publication on acceptance

- support for research data, including large and complex data types

- gold Open Access which fosters wider collaboration and increased citations

- maximum visibility for your research: over $100 \mathrm{M}$ website views per year

At BMC, research is always in progress.

Learn more biomedcentral.com/submissions 